\title{
Optimization of Sapta Pesona (Seven Enchantments) with Waste Management on Tourist Village Development: Case of Cimande Tourist Village
}

\author{
Maidar Simanihuruk \\ Sekolah Tinggi Pariwisata Bogor \\ Corresponding Author: meydar_bj@yahoo.co.id
}

\begin{abstract}
ARTICLE INFO
Received

9 September 2020

Accepted

18 September 2020

Available online

30 September 2020
\end{abstract}

Through the community-based tourist approach, coaching of the Sapta Pesona program is one way to provide knowledge to the community that area they live in is a tourist area. Tourists will visit if the area is safe,orderly, clean, cool, beautiful, friendly and memories. The purpose of this research is to know community public awareness of cleanliness, determine the distribution and volume of waste, the waste management evaluation system that has been carried out, and environmental management at Cimande Tourist Village. The Method of research used is qualitative and quantitative methods in order to obtain more comprehensive, valid, reliable, and objective data. The sample consists of 35 participants of coaching from community of Cimande Village. The factor and regression analysis were used for the data analysis. The results of the study showed that coaching significantly contributed to the community interest in waste management $(\mathrm{t}=2.512>\mathrm{t}$ table with a significance of $0.017(\rho<0.05)$. The distribution of the generated waste accumulates in almost every RT (neighborhood) and there are 20 illegal landfill garbage dumps. The author makes a suggestion, Urban Village Head with Pokdarwis, Village Cadres and Youth Organization had to have a program to invite all Cimande community to do environmental cleanliness by mutual cooperation on regularly in order to optimize cleanliness with waste management to achieve Cimande Clean, reach out to people from door to door, making them realize the importance of cleanliness and segregation of waste.

Keywords: Sapta Pesona, Seven Enchantments, Waste Management, Tourist Village, Cimande 


\section{INTRODUCTION}

\section{Background}

In accordance with the direction of the President of the Republic of Indonesia Joko Widodo, which is to develop Indonesia from the periphery with regions and villages within the framework of unity is with the idea of a village and Tourist, and then the idea of a tourist village emerged. This directive succeeded in elevating several villages to become tourist destinations. Through village development, it is hoped that rural communities will gain insight into awareness of the protection of the natural environment, sustainable culture, and be able to empower the available resources, remain diligent in carrying out daily habits, and carry out their main livelihood. So that it is expected to be a tourist attraction.

This type of special interest Tourist can be offered in a tourist village, where there is more emphasis on experiential elements and active Tourist that involves tourists in direct contact with the surrounding community. One of the villages that is currently developing local cultural Tourist with its trademark Cimande Silat is the Cimande Tourist Village located in Caringin District, Bogor Regency.

Cimande Village is a developing Tourist village located in Bogor Regency, famous for its medical Tourist 'fracture http://ojs.unud.ac.id/index.php/eot massage' and culture Tourist 'Pencak Silat'. In this location, various human activities are centralized, both local residents, patients seeking treatment, patient companions, tour operators, and visitors / tourists. Activities carried out directly and indirectly cause damage to the environment, such as piles of organic waste and plastic waste, rubbish scattered on the side of the road. If this condition is not immediately addressed, it can threaten the environment and sustainable community life.

Cleanliness is an environmental condition that displays a free atmosphere, from dirt, garbage, sewage and pollution. The pollution factor or vision of tourists in terms of cleanliness in a location or village environment will affect the interest of the tourists to return or no longer to the location or village. To realize the interest of tourists visiting an area, it can be realized with Sapta Pesona. The community should be able to create a beautiful atmosphere of enchanting, clean as well as create interesting and comfortable conditions and atmosphere for the tourists. Clean, where Tourist Village provides conditions that show clean and hygienic properties such as environmental conditions, Tourist facilities, service equipment and human beings who provide such services. 
The volume of waste generation always increases with the increase in population. Based on information from the Ministry of Environment and Forestry (KLHK), the national waste generation amount reaches 175,000 tons per day if using the assumption that $0.7 \mathrm{~kg}$ of waste produced per person per day is assumed. The total population of Cimande Village is 6,800 people, so the assumption of the amount of waste generated by multiplying the assumption of waste generated by each person per day is $4,760 \mathrm{~kg}$ per day.

Preventing the implementation of landfills and environmental damage is necessary for waste management at Cimande Tourist Village. As a developing Tourist village, village communities who need awareness in waste management, this research aims to monitor the distribution and volume of waste at this Village, the waste management evaluation system that has been carried out, and environmental management at Cimande Tourist village which is free of waste. Through a community-based Tourist approach, it is hoped that the community will be wiser in managing and a sustainable village environment free of waste. As a Tourist village, the application of the Sapta Pesona concept is important in its foundation because it can encourage public awareness to be good hosts. In addition, the application of Sapta Pesona will also attract http://ojs.unud.ac.id/index.php/eot tourists to an area, thereby increasing the role of the community as the maximum beneficiary of the development of Tourist activities.

\section{Formulation of the problems}

Based on the background description above, the formulation of the problems are as follows:

1. What is the distribution and volume of waste in the Cimande Tourist Village area?

2. What is the waste management system in the Cimande Tourist Village?

3. What is the environmental management strategy in the Cimande Tourist Village?

\section{LITERATURE REVIEW}

\section{Sapta Pesona}

In order to attract his interest in visiting an area, Sapta Pesona can be realized. The community must be able to create a beautiful, enchanting atmosphere and create attractive and comfortable conditions and atmosphere for tourists. Tourists will feel at home staying longer, satisfied with their visit and giving beautiful memories in their life. The seven elements of Sapta Pesona, namely: (1) Safety, where a condition that can be felt and experienced a safe atmosphere, free 
from threats, disturbances, and acts of violence and crime, is protected, (2) Orderliness, which provides conditions that reflect orderly and orderly and discipline in all aspects of community life both in terms of vehicle traffic, use of facilities as well as in various other community behaviors, (3) Cleanliness, where the conditions are clean and hygienic in both environmental conditions, Tourist facilities, service equipment and human beings provide these services, (4) Cool Atmosphere, providing a fresh, cool and comfortable atmosphere because of regular and beautiful reforestation both in the form of parks and greening in each residential environment, (5) Beauty, which provides beauty, conditions that reflect the arrangement that orderly, orderly and harmonious both regarding infrastructure, facilities, use of a harmonious color scheme, in harmony with de with the environment and showing national personality traits, (6) Friendliness, which provides warm hospitality, namely the attitude and behavior of people who are friendly and polite in communicating, providing services and helping hands without strings attached; (7) Memories, which give memories, namely pleasant impressions and will always be remembered.

\section{Waste}

Garbage is solid, solid waste or waste which is a byproduct of urban areas or the life cycle of humans, animals or plants. Garbage is goods that are not used and wasted or items whose owner / user or ordered have been disposed of with the intention of not being taken away (Kodoatie, 2005; Siahaan, 2016). According to the Indonesian National Standard (SNI) Number T-13-1990, what is meant by waste is solid waste containing useless organic and inorganic substances and must be managed so that it does not apply to the environment and protect building investment.

\section{Waste Management}

Based on the Regional Regulation of Bogor Regency Number 2 of 2014, waste is the residue of human daily activities and / or natural processes in solid form, consisting of household waste and household-like waste. If waste management does not receive serious attention and is only considered a "small thing" for the community and is not managed seriously, it will become "big and scary" in the future. In order to achieve optimal solid waste services, it is time for a paradigm shift in waste management. According to the Law of the Republic of Indonesia Number 18 of 2008 concerning waste management, it is a comprehensive and continuous systematic e-ISSN: 2407-392X. p-ISSN: 2541-0857 
activity which includes waste reduction and handling. Waste management is a process that needs to be done with the aim of converting waste into something that has economic value and breaking waste into something that is not endangering the environment (Masjhoer, 2017).

To achieve optimal solid waste services, it is time for a transformative paradigm shift in waste management at Cimande Tourist Village. The transformative paradigm is the concept of waste management at Cimande Tourist Village, which can prevent or minimize pollution and other negative impacts that are detrimental to society and the environment. According to (Witoelar, 2006; Siahaan, 2016) new policies are needed to change the paradigm of waste management from the end of pipe approach, namely disposing of waste directly to the landfill towards waste management with the $3 \mathrm{R}$ principle, namely Reduce, Reuse and Recycle. Waste management policy emphasizes reducing waste at its source, sorting and recycling. The initial step that is very important in changing this paradigm is to change the policy towards minimizing waste at its source, not at its disposal.

\section{The Impact of Tourist on the Environment}

Tourist can have a negative or positive impact on the environment, depending on the planning and management of Tourist development in a destination (Gee, 1997; Masjhoer, 2017). General impacts arising from Tourist (Inskeep, 1991; Masjhoer, 2017):

1. Positively impact. If Tourist has good planning and management, it can maintain and improve environmental conditions in various ways. Positive impacts of Tourist, namely: conservation of protected areas, conservation of archaeological and historical sites, improvement of environmental quality, improvement of the environment, improvement of infrastructure, and increasing environmental awareness.

2. Negative impact. Tourist development that does not have proper planning, development and management will have a negative impact on the environment. The negative impacts may vary depending on the type of Tourist development and the specific environmental characteristics of the Tourist area. The relationship between the scale of Tourist development and the carrying capacity of the environment greatly affects the 
expansion of the resulting environmental impacts. The negative impacts of Tourist are water pollution, air pollution, noise, visual pollution, waste problems, ecological disturbances, damage to archaeological and historical sites, and land use problems.

\section{Coaching}

Coaching from a humanist perspective is person-centered principles, it views positive change and selfactualization as a driving force in the human psyche (Roger, 1959; Ives, 2008).

Behavior based approach, advocates a behavioral approach that acknowledges the complexity of both the human being and her environment, but which nevertheless focuses on facilitating practical change over psychological adjustments. This approach is action focused insofar as it looks to the future and seeks to create change and imbed it in real life contexts, but it still leans heavily towards personal development, emphasizing the need for client learning, and to a lesser degree adopts a therapeutic emphasis on the coaching relationship (Stober, Wildflower, \& Drake, 2006; Ives, 2008).

According to (Whitmore, 2003; Ives, 2008) portrays coaching as “optimizing people's potential and performance.”. To coach means to convey http://ojs.unud.ac.id/index.php/eot a valued colleague from where he or she is to where he or she wants to be (Evered \& Selman, 1989; Ives, 2008), "to focus, motivate and support others in achieving their goal" (Parsloe \& Wray, 2000; Ives, 2008), "collaborative solution-focused, result-orientated and systematic process in which the coach facilitates the enhancement of life experience and goal attainment in the personal and/or professional life of normal, non-clinical clients (Grant, 2003; Ives, 2008). Coaching is an intervention aimed at helping the coaches to focus on and achieve their clearly defined goals. The coach uses openended questions to provoke thought, raise awareness, and to inspire motivation and commitment.

\section{METHODOLOGY}

\section{Research Location and Time}

This research was conducted at the Cimande Tourist Village located in area Tarikolot, Kecamatan Caringin, Bogor Regency for five months, from January 2020 to February 2020, and continued again on July 2020 to September 2020 due to the Covid Pandemic from March 2020 to June 2020. The research began from the process of data collection until completion. This Research focus on optimizing Sapta Pesona with waste management in the development of Cimande Tourist Village. 
This research is expected to help the community in providing knowledge about the importance of cleanliness through Sapta Pesona Coaching. So that it can change the behavior of people who care about the environment and are aware that the area they live in is a tourist area that tourists will always visit if the area is clean, beauty, comfortable, orderly, and safe. Through a community-based Tourist approach, it is hoped that the community will be wiser in maintaining and managing a sustainable village environment free of waste. As for the general research roadmap carried out during five months, from January 2020 to Feb 2020 and July 2020 to September 2020, as follows

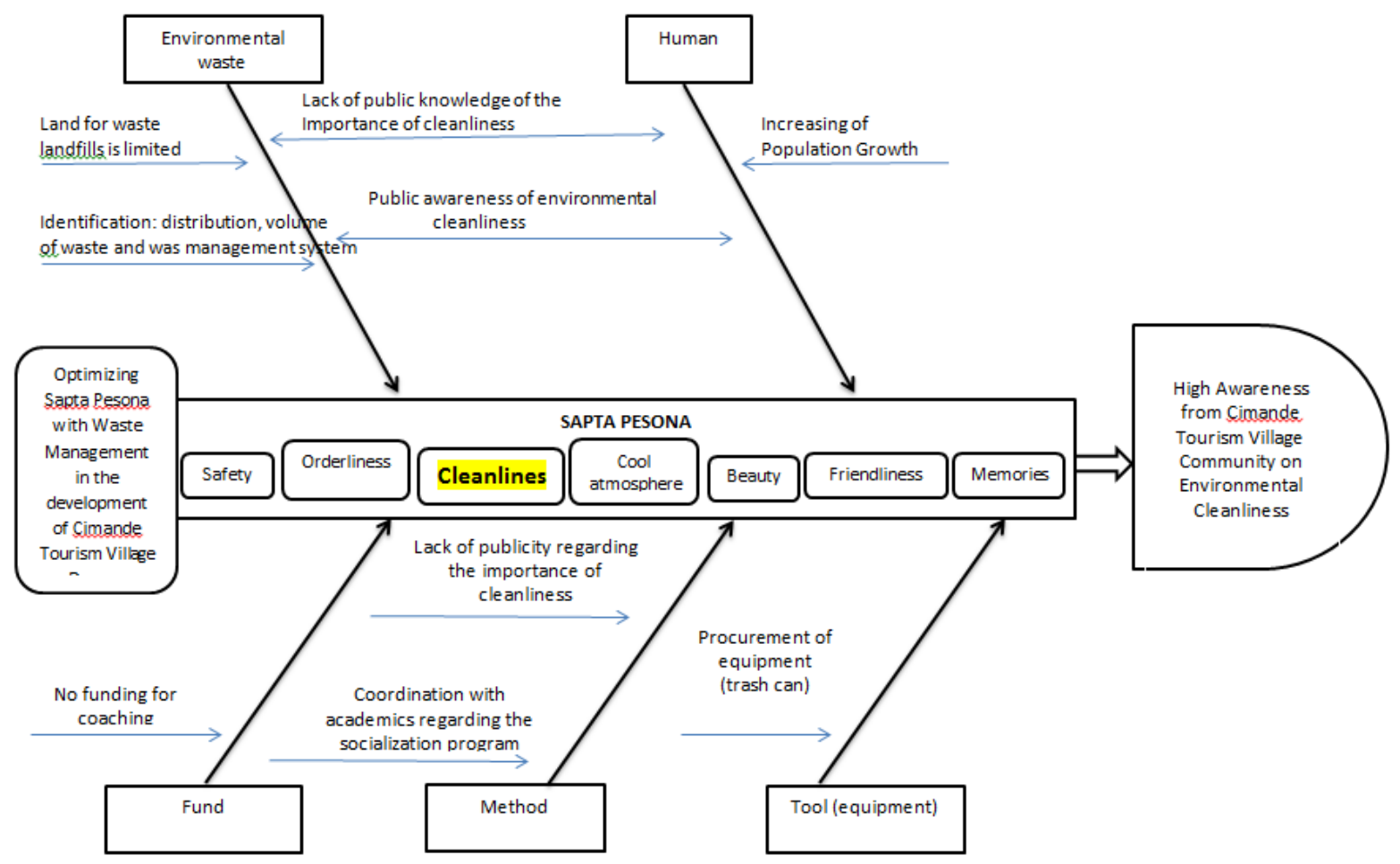

Figure 1. Research Roadmap (2020)

The research activities that have been carried out are identifying the volume of waste generation that follows the population. Village communities need awareness in waste management and environmental management that is free of waste. With the application of the Sapta Pesona concept as the basis for its development in order to encourage high awareness of the Cimande Village community in environmental cleanliness.

\section{Data Types and Sources}

The type of research data consisted of qualitative data consisting of an overview of the Cimande Tourist Village 
and quantitative data which included the number of participants who attended in the Counselling of the Sapta Pesona with waste management on tourist village development, the characteristics of participant and the answers to the questionnaire statements obtained from participant. Data sources used in this research were obtained from primary data sourced from direct respondents and secondary data not sourced from respondents.

\section{Data Collecting}

Both the qualitative and quantitative data were used in the current research. The data were obtained from both the primary and secondary data sources. The data were collected through the library research and field research (observation, direct interview, questionnaire, and documentation). Data collection in this research was conducted through observations, interviews, documentation and library studies.

\section{Research Population and Samples}

The research sampling is based on the requirements of the regression analysis in which the requirements for the number of samples are between 30 to 100. The number of research samples is 35 respondents with the consideration that the number has met the minimum requirements in the analysis http://ojs.unud.ac.id/index.php/eot using Statistical Package for Social Sciences (SPSS) computer program version 22. The sampling technique is done by probability sampling of simple random sampling technique that is simple to accomplish and easier to explain to others without paying attention to the strata in the population. Sampling of respondents was done by 35 people for participant who attended in the Coaching of the Sapta Pesona with waste management on tourist village development.

\section{Variables and Data Analysis}

The completed and structured close-ended questionnaires were coded and keyed in the Statistical Package for Social Sciences (SPSS) computer program version 22 and descriptive analysis such as means, standard deviation, and correlation analysis was performed. Next, further investigation using hierarchical regression analysis was executed to assess the relationship between a set of one independent variable and the dependent variable, controlling the effect of a different set of independent variables: Coaching on the dependent variable: Community Interest in waste management, which thereafter could furnish empirical findings in supporting the outlined research objectives.

e-ISSN: 2407-392X. p-ISSN: 2541-0857 


\section{RESULTS AND DISCUSSION}

Cimande Tarikolot Village is one of the villages in the Caringin District, Bogor Regency, which is located between two hills, Mount Pangrango and Mount Salak. The village of Cimande Tarikolot is bordered by Pancawati Village in the north, in the east it is bordered by Sukabumi Regency and borders with Lemahduhur Village in the West and South. The distance of Cimande village from the center of Caringin district is about $5 \mathrm{~km}$, from the center of Bogor Regency about $34 \mathrm{~km}$ and from the national capital about $70 \mathrm{~km}$. With an area of $+335 \mathrm{Ha}$, an altitude of $550 \mathrm{M}$ above sea level, divided into 2 urban villages, 4 RW (hamlet) and 17 RT (neighborhood). Residential area of 252 ha with a population of 6,800 inhabitants. The population distribution is not evenly distributed in each RT (neighborhood). The areas with the densest population are RT 11 to RT 15, with an average number of over 130 households and the rest averaging around 100 households. The majority of residents $(53 \%)$ are men, consisting of 1,702 heads of families spread over 2 urban villages, 4 RW (hamlet) and 17 RT (neighborhood).. The education level of the village community, the majority are Primary School (SD) 60\%, Middle School (SMP) 22\%, High School (SMA) / SMK graduates $12 \%$, the rest are kindergarten http://ojs.unud.ac.id/index.php/eot and bachelor's $1.6 \%$ graduates. The majority of people's livelihoods are farming, self-employed, employees, traders, farm laborers.

\section{Demographic Characteristics of Respondents}

In table 2 depicts the respondents' demographic characteristics of respondent. Male respondents made up 37 percent of the sample while females made up 63 percent. The respondents who attended in the Counselling of the Sapta Pesona with waste management on tourist village development are dominated aged 36-45 years (57 percent) because of some of them are Village Cadres of Cimande Tourist Village. They get information about Sapta Pesona made up 69 percent are obtained from Coaching from the Government Tourist Service \& Academic. 
Table 1. The Distribution of Demographic Characteristics

\begin{tabular}{|c|c|c|c|c|c|c|c|c|}
\hline \multicolumn{9}{|c|}{ Demographic Characteristics } \\
\hline A. Gender & $\boldsymbol{F}$ & $\%$ & & B. & Age & $F$ & & $\%$ \\
\hline Male & 13 & 37 & & & $18-25$ & 6 & & 17 \\
\hline \multirow[t]{3}{*}{ Female } & 22 & 63 & & & $26-35$ & 2 & & 6 \\
\hline & & & & & $36-45$ & 20 & & 57 \\
\hline & & & & & $46-55$ & 7 & & 20 \\
\hline \multicolumn{2}{|l|}{ C. Education } & $F$ & $\%$ & $D$. & Occupation & $\boldsymbol{F}$ & & $\%$ \\
\hline \multicolumn{2}{|c|}{ Primary School } & 16 & 46 & Far & m Laborer & 10 & & 29 \\
\hline \multicolumn{2}{|c|}{ Middle School } & 1 & 3 & & Village Cadres & 14 & & 40 \\
\hline \multicolumn{2}{|c|}{ High School } & 15 & 43 & Yo & uth Organization & 2 & & 6 \\
\hline \multicolumn{2}{|c|}{ University } & 3 & 9 & & tbang \& Babinsa & 2 & & 6 \\
\hline \multicolumn{2}{|l|}{ Doctoral } & & & $\begin{array}{r}\text { Touris } \\
(\end{array}$ & $\begin{array}{l}\text { Awareness Groups } \\
\text { Pokdarwis) }\end{array}$ & 7 & & 20 \\
\hline \multicolumn{6}{|c|}{ E. Source Information about Sapta Pesona } & $F$ & $\%$ & \\
\hline \multicolumn{6}{|c|}{ Social Media/Advertising } & 2 & 6 & \\
\hline \multicolumn{6}{|c|}{ Coaching from Academic } & 7 & 2( & \\
\hline \multicolumn{6}{|c|}{ Coaching from the Government Tourist Service \& Academic } & 24 & 6 & \\
\hline \multicolumn{6}{|l|}{ Seminar } & 1 & 2 & \\
\hline \multicolumn{6}{|l|}{ Friends } & 1 & 2 & \\
\hline \multicolumn{2}{|l|}{ TOTAL } & & 10 & TO & TAL & & 35 & 100 \\
\hline
\end{tabular}

Source: The Processed Primary Data (2020)

\section{Results of Observation}

The distribution of the generated waste at Cimande Village accumulates in almost every RT (neighborhood). Each RT (neighborhood) has at least one illegal landfill (garbage dump). However, there are several RT (neighborhood) that have more than one illegal garbage dump, such as RT 08 which has 5 illegal dumping points. So that in the entire village there are 20 illegal landfill garbage dumps.

Local waste originating from household rubbish is a source of permanent waste generation, where the volume of waste is very large and relatively constant. Based on information from the Ministry of http://ojs.unud.ac.id/index.php/eot
Environment and Forestry (KLHK), the national waste generation amount reaches 175,000 tons per day if using the assumption that $0.7 \mathrm{~kg}$ of waste produced per person per day is assumed. The total population of Cimande Village is 6,800 people, so the assumption of the amount of waste generated by multiplying the assumption of waste generated by each person per day is $4,760 \mathrm{~kg}$ per day. 

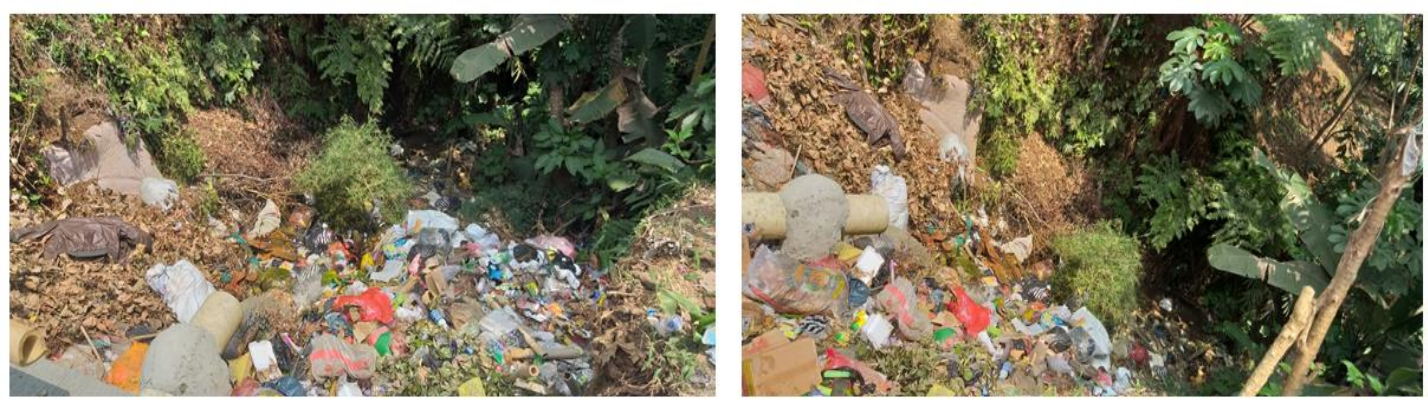

Figure 2. Waste Generations in Sewers, RT 11, Cimande Village Source: Researcher's Personal Documents (2020)
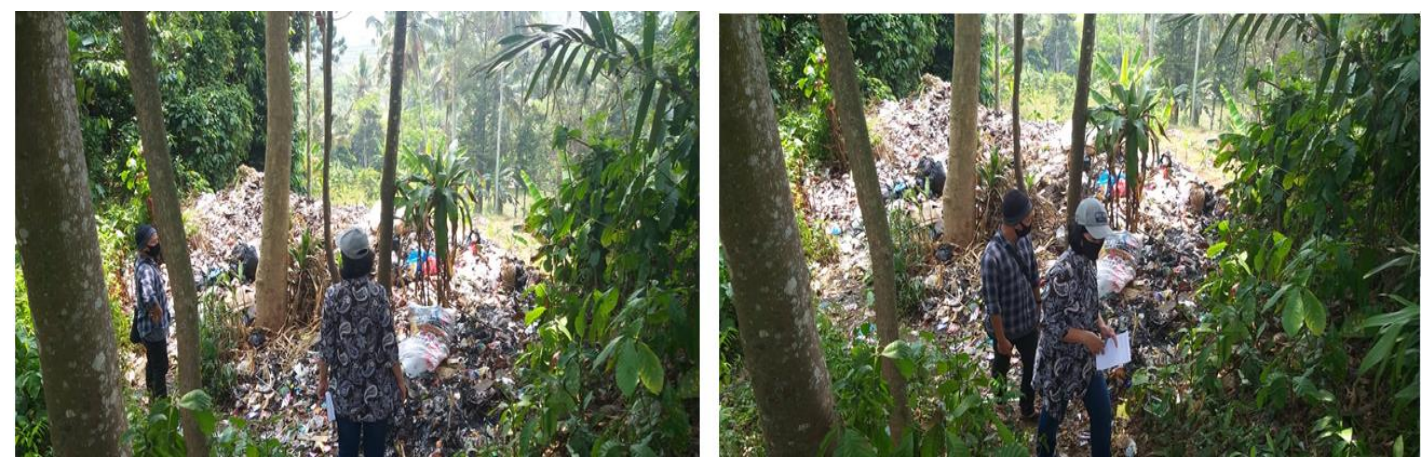

Figure 3. Waste Generation in green area, RT 09, Cimande Village Source: Researcher's Personal Documents (2020)
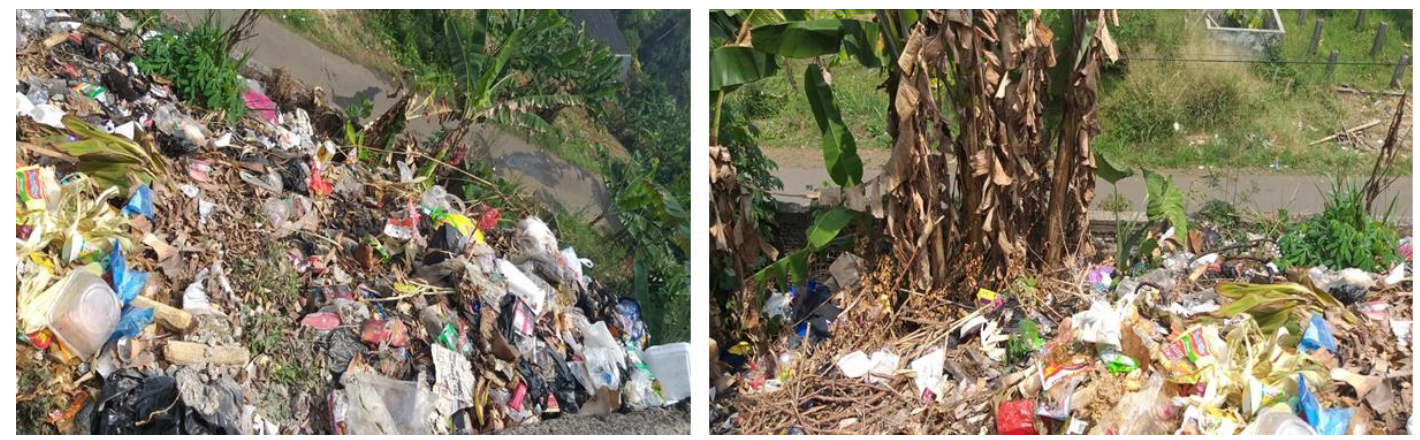

Figure 4. Waste Generation near the grave, RT 08, Cimande Village Source: Researcher's Personal Documents (2020)
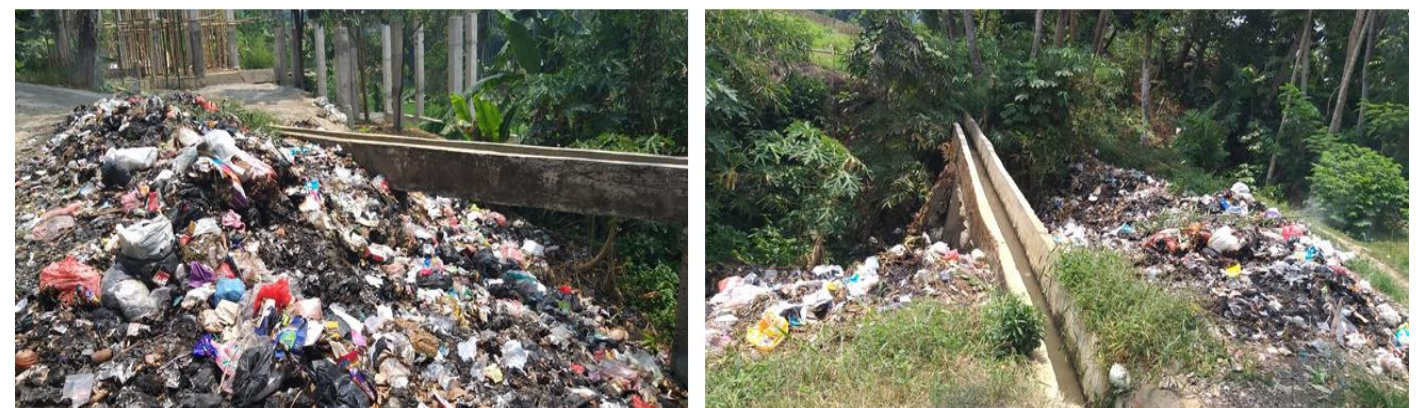

Figure 5. Waste Generation in sewers, RT 08, Cimande Village Source: Researcher's Personal Documents (2020) 
Waste Management in Cimande Village Local government participation

The role and local government in the waste management strategy in the form of providing the necessary facilities and infrastructure, including the number of cleaners who act as implements every day is not yet visible. The unavailability of TPS (Temporary Disposal Sites) has resulted in the community dumping garbage in illegal dumpsites, such as in several garbage dumps that are in sewer airways or in landfills without permanent buildings in every neighborhood unit at Cimande Village. The accumulation of garbage that has never been collected becomes sedimentation so that it closes the airways of the sewers and even creates an unpleasant odor that pierces the residents' noses. The presence of black smoke and burns in what is called an illegal TPS (Temporary Disposal Site) and plastic, organic and other garbage mixed together.

There is no role and local government in waste management efforts at the Cimande Village through Coaching on waste management. The extension is an important part of providing knowledge about waste to the community, so that the community understands how importance of waste management and is willing to get involved in waste management strategies. Karang Taruna as a community social youth organization in Cimande Village has http://ojs.unud.ac.id/index.php/eot just started to reactivate their activities in early 2020. One of the programs carried out by Karang Taruna is to help with waste management strategies in the form of taking garbage from house to house in several RT, namely in RT $01,02,03$ and 06 due to personnel and funding limitations. Waste management activities began on June 15, 2020. The mechanism for collecting garbage from house to house by assigning five persons personnel cleaning for each RT, which is carried out every Wednesday night. The waste that is taken is then collected into sacks and then carried by the cleaning staff to be collected by the designated roadside. On Wednesday morning, DLH (Environmental Service) officers will transport the garbage sacks and bring them to the Leuwiliang TPA (Final Disposal Site).

The form of financing carried out by the community in RT 01, 02, 03 and 06 is to pay rubbish disposal fees every month. This levy is managed independently by the Karang Taruna group to pay the cleaning staff that every Wednesday night picks up trash. The amount of rubbish retribution is IDR 15,000 per household / month. The amount of this fee is for the cost of transporting waste from the house to the Leuwiliang landfill (TPA). IDR 5,000 for each five persons personnel cleaning and IDR 10,000 for fee of DLH (Environmental Service) officers. 

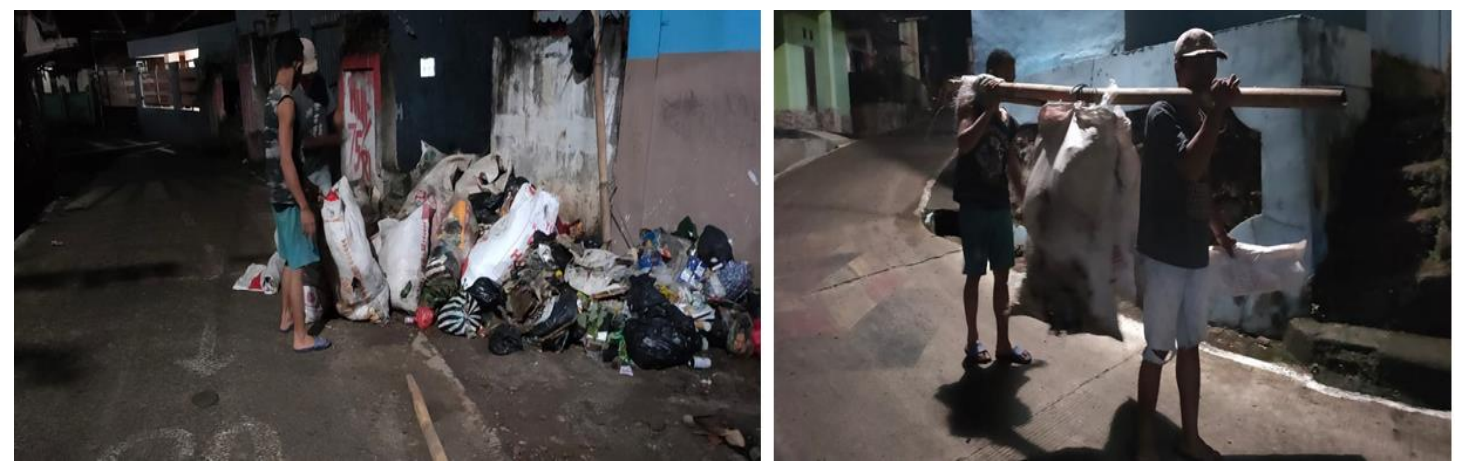

Figure 6. Process Collecting the Rubbish

Source: Researcher's Personal Documents (2020)

The behavior of the people who do not care about the environment needs to be changed. This is not easy, because changing behavior is something that cannot be done in a matter of hours or days. The method that can be done is with socialization that is able to touch all levels of society intensively and continuously. In order to optimize Sapta Pesona with waste management in the development of the Cimande Tourist Village, there are strategies that is carried out, as follow:

\section{Coaching from Academy}

Coaching of the Sapta Pesona program is one way to provide knowledge to the community that the area they live in is a tourist area that tourists will visit if the area is safe, orderly, clean, cool, beautiful, friendly and memories. The objective of the Sapta Pesona program extension is to increase awareness and sense of responsibility for all levels of the Cimande Village community to be able to act and make it happen in everyday life. The purpose of this coaching is to change http://ojs.unud.ac.id/index.php/eot people's behavior in order to: don't dispose of rubbish improperly and to participate in maintaining the cleanliness of the facilities and environment of tourist objects and attractions.

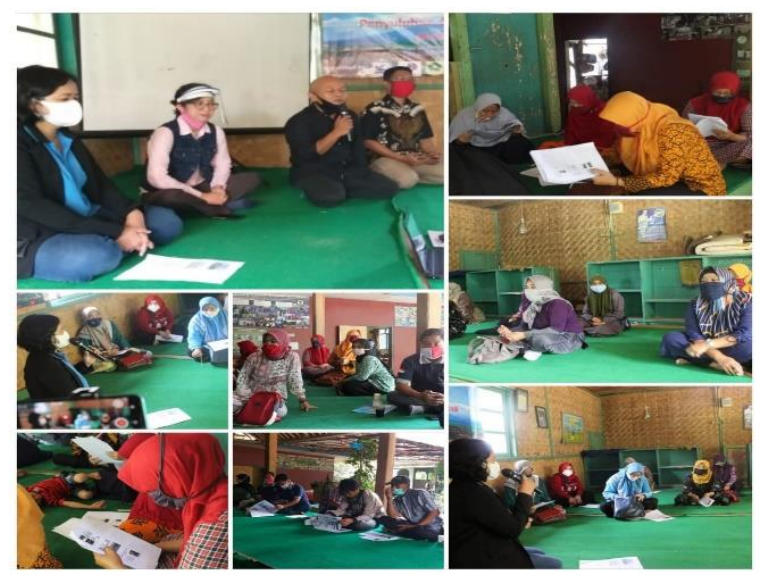

Figure 7. Coaching from Academy Source: Researcher's Personal Documents (2020)

After completion of the coaching, the researcher gave the participants a questionnaire form to see if they had any interest in making improvements in waste management so don't dispose of rubbish improperly and to participate in maintaining the cleanliness of the facilities and environment of tourist objects and attractions. 
Table 2. Community Interest in Waste Management

\begin{tabular}{lll}
\hline Question & \multicolumn{1}{c}{ F } & $\%$ \\
\hline 1. Willing to implement the 3R program (reduce-reuse-recycle) & Scale 4: 10 & 28.6 \\
& Scale 5: 25 & 71.4 \\
2. Willing to have own rubbish can & Scale 4: 5 & 14.3 \\
& Scale 5: 30 & 85.7 \\
3. Will throw trash in own rubbish can & Scale 1: 1 & 2.9 \\
& Scale 3: 2 & 5.7 \\
& Scale 4: 4 & 11.4 \\
4. Willing to do cleanliness the environment with mutual & Scale 5: 28 & 80 \\
cooperation every month & Scale 4:8 & 22.9 \\
TOTAL & Scale 5: 27 & 77.1 \\
\hline
\end{tabular}

Source: The Processed Primary Data (2020)

In table 2 , describes the results of coaching. The answer of the community strongly agrees to be willing to implement the 3R (reduce-reuse-recycle) program, want to have their own trash cans, want to throw garbage in their own trash cans and want to do environmental cleanliness by mutual cooperation every month.

\section{Rubbish can}

Make rubbish can with bamboo material. Cimande Village has many bamboo trees that can be used as trash cans. Garbage bins are also distinguished by organic and inorganic waste, where this will facilitate the sorting of waste and further waste utilization. The placement of these trash cans at several points per RT (neighborhood) is to pull out the trash and collect the garbage so that a clean environment is created. According to Khalik (2014: 29) the condition of the

environment around the tourist area must be maintained by not littering and maintaining cleanliness at public facilities because littering can affect the comfort of tourists in visiting.
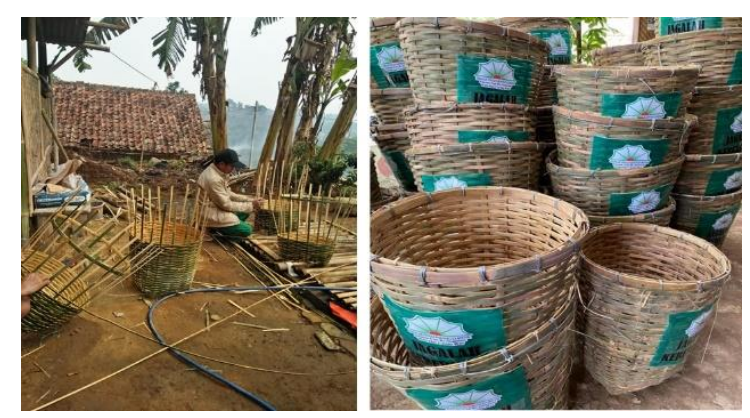

Figure 8. Making Rubbish Baskets by the Community

Source: Researcher's Personal Documents (2020)

\section{Reliability Analysis}

Reliability refers to a sense that the instrument used in research to obtain the desired information can be trusted (reliably) as a data collection tool and able to reveal actual information in the field. The reliability test method used is the 
Cronbach's Alpha method, construct is considered reliable if the Alpha coefficient is> 0.70 (Sugiarto, Hendratono, \& Djoko, 2015). The reading of Cronbach's $\alpha$ for all the variables as described in Table 3 exceeds the criterion of 0.70 , indicating the survey instrument is reliable to measure all constructs consistently and is free from random error.

Table 3. Reliability Analysis

\begin{tabular}{lcc}
\hline Variables & Number of Items & Cronbach's Alpha \\
\hline Coaching & 9 & .781 \\
Community Interest in Waste Management & 4 & .821 \\
\hline
\end{tabular}

Source: The Processed Primary Data (2020)

\section{Descriptive statistics}

The descriptive statistics for respondent response of the effect of
Coaching on Community Interest in Waste Management is presented in Table 4.

Table 4. Respondent Response of The Eeffect of Coaching on Community Interest in Waste Management

\begin{tabular}{llll}
\hline & Labels & Means & SD \\
\hline Variable: Coaching & C1 & 4.86 & .355 \\
& C2 & 4.71 & .622 \\
& C3 & 4.89 & .323 \\
& C4 & 4.74 & .443 \\
& C5 & 4.89 & .323 \\
& C6 & 4.51 & .781 \\
& C7 & 4.14 & .944 \\
& C8 & 4.46 & .701 \\
& C9 & 4.37 & .843 \\
\hline & Labels & Means & SD \\
\hline & P1 & 4.71 & .458 \\
Variable: & P2 & 4.86 & .355 \\
Community Interest in Waste & P3 & 4.66 & .838 \\
Management & P4 & 4.77 & .426 \\
& & &
\end{tabular}

Source: The Processed Primary Data (2020) 
The multi-item statements are designed for a five-point Likert scale ranging from 1 (strongly disagree) to 5 (strongly agree). As seen in table 3 above, the highest mean value is on C3 and C5 indicator statement which is at an average of 4.89 which means that respondents agree that the speaker was friendly and had a pleasant personality and the material presented was in accordance with the conditions in Cimande Tourist Village.
On $\mathrm{P} 2$ indicator statement is at an average of 4.86 which means that respondents are willing to have their own trash can.

The standard deviation value not all has a value close to 1 (whole number) which means that the diversity of respondents gives answers homogeneous and not homogeneous in providing answers to Coaching which means that some of answers given by respondents vary and another respondent gives same answers.

Table 5. Respondent Response of Understanding and Knowing Information about Sapta Pesona

\begin{tabular}{llll}
\hline Question & Labels & Means & SD \\
\hline * One of the government's Tourist programs is Sapta Pesona & SP1 & 4.49 & .742 \\
* The objectives of implementing the Sapta Pesona program & SP2 & 4.26 & 1.01 \\
* The Sapta Pesona Program is beneficial for Cimande & & & \\
$\quad$ Tourist Village Environment & SP3 & 4.80 & .406 \\
* The Sapta Pesona Program can be applied at & & & \\
Cimande Tourist Village & SP4 & 4.34 & .684 \\
* Society applies Sapta Pesona points & SP5 & 4.03 & .923 \\
* Society's attitude towards Sapta Pesona & SP6 & 4.71 & .750 \\
\hline
\end{tabular}

Source: The Processed Primary Data (2020)

As seen in table 5, the highest mean value is on SP3 indicator statement which is at an average of 4.80 which means that respondents agree that the Sapta Pesona Program is beneficial for Cimande Tourist Village Environment and 71 percent respondents agree that the most difficult thing to do from the seven points of Sapta Pesona, is cleanliness (table 6).
Table 6. Respondent Response: Difficulty of Doing Sapta Pesona

\begin{tabular}{lcc}
\hline Sapta Pesona & $\boldsymbol{F}$ & $\%$ \\
\hline $\begin{array}{l}\text { Safety } \\
\text { Orderliness } \\
\text { Cleanliness }\end{array}$ & 25 & 71 \\
$\begin{array}{l}\text { Cool Atmosphere } \\
\text { Beauty }\end{array}$ & 3 & 9 \\
$\begin{array}{l}\text { Friendliness } \\
\text { Memories }\end{array}$ & & \\
\hline No Answer & 7 & 20 \\
\hline
\end{tabular}

Source: The Processed Primary Data (2020) 
Results of the Regression Analysis

Simple Correlation Analysis is used to determine the relationship between one independent variable to the dependent variable. Determination analysis in simple regression is used to determine the percentage contribution of the influence of the independent variable on the dependent variable (Sugiyono, 2016).

Table 7. The Effects of Coaching on Community Interest in Waste Management

\begin{tabular}{cllcc}
\hline Variable & R & R Square & Adjusted R Square & Std. Error of the Estimate \\
\hline $\mathrm{X}$ & .401 & .161 & .135 & 1.658 \\
\hline
\end{tabular}

Source: The Processed Primary Data (2020)

As seen in table 7, correlation among coaching on community interest in waste management are seen. The $\mathrm{R}$ number is 0.401 , this shows that there is a moderate relationship between Coaching on Community Interest in Waste Management. The determination coefficient is obtained by R2 ( $\mathrm{R}$ Square) by 0.161 for $\mathrm{X}$. This shows that the percentage contribution of the influence of Coaching on Community Interest in waste management by $16.1 \%$ while $83.9 \%$ is influenced by other variables not examined.

Table 8. Hypothesis Testing Results

\begin{tabular}{llll}
\hline Hypothesis & \multicolumn{1}{c}{ Statement } & Score & Remarks \\
\hline $\mathrm{H}_{\mathrm{a}}$ & $\begin{array}{l}\text { Coaching Significant Effect } \\
\text { on Community Interest in Waste } \\
\text { Management }\end{array}$ & $\mathrm{t}=2.512$ & $\mathrm{sig}=0.017$ \\
& $\mathrm{H}_{1}$ accept & $\mathrm{H}_{0}$ reject \\
\hline
\end{tabular}

Source: The Processed Primary Data (2020)

In Table 8, the results of the t-test analysis related to Coaching on Community Interest in Waste Management, the $\mathrm{t}_{\text {count }}>\mathrm{t}_{\text {table }}$ was obtained; $2.512>1.692$ with a significance of $0.017(\rho<0.05)$. The positive $t$ value indicates that the Coaching has a direct relationship with Community Interest in waste management. So, it can be concluded that the Coaching has a significant http://ojs.unud.ac.id/index.php/eot influence on Community Interest in waste management.

\section{CONCLUSIONS}

Based on the results of the study, several conclusions can be drawn as follows:

e-ISSN: 2407-392X. p-ISSN: 2541-0857 
1. The distribution of the generated waste in Cimande Village accumulates in almost every RT (neighborhood) and there are 20 illegal landfill garbage dumps. Local waste originating from the activities of local residents is a source of permanent waste generation, where the volume of waste is very large and relatively constant. The total population of Cimande Village is 6,800 people, so the assumption of the amount of waste generated by multiplying the assumption of waste generated by each person per day is $4,760 \mathrm{~kg}$ per day.

2. The waste management system in the Cimande Tourist Village in the form of providing the necessary facilities and infrastructure, including the number of cleaners who act as implements every day is not yet visible. The unavailability of TPS has resulted in the community dumping garbage in illegal dumpsites There is no role and local government in waste management efforts in the Cimande Village through Coaching on waste management. Karang Taruna as a community social organization in Cimande Village has just started to help with waste management strategies in the form of taking garbage from house to house in several RT (neighborhood), in RT 01, 02, 03 and 06. Waste management activities began on June 15,2020 . The mechanism for collecting http://ojs.unud.ac.id/index.php/eot garbage from house to house by assigning five persons personnel cleaning for each RT, which is carried out every Wednesday night. The waste that is taken is then collected into sacks and then carried by the cleaning staff to be collected by the designated roadside. On Wednesday morning, DLH (Environmental Service) officers will transport the garbage sacks and bring them to the Leuwiliang TPA (Final Disposal Site).

3. In order to optimize Sapta Pesona with waste management in the development of the Cimande Tourist Village, there is a strategy that is carried out. Coaching of the Sapta Pesona program is one way to provide knowledge to the community that the area they live in is a tourist area that tourists will visit if the area is safe, orderly, clean, cool, beautiful, friendly and memories. The results of coaching, community strongly agrees to be willing to implement the $3 \mathrm{R}$ (reducereuse-recycle) program, want to have their own trash cans, want to throw garbage in their own trash cans and want to do environmental cleanliness by mutual cooperation every month. The effect of coaching has a positively and significantly contributed to community interest in waste management at Cimande Tourist village 


\section{SUGGESTIONS}

Bogor Regency Regional Regulation No. 2 (2014) concerning Waste Management, namely in order to create a healthy and clean Bogor Regency from waste that tends to increase and the volume, type and things that can have a negative impact on health and environmental pollution, so it is necessary to carry out waste management. Local government (Urban Village Head) can impose strict sanctions in order to provide a deterrent effect and educate the community to raise more awareness about maintaining a clean environment and has to have a program to invite all Cimande community to do environmental cleanliness by mutual cooperation every month in order to optimize Cleanliness with waste management in the development of the Cimande Tourist Village to achieve Cimande Clean. Tourist Awareness Groups (Pokdarwis), Village Cadres and Youth Organization (Karang Taruna) have to reach out to people from door to door, making them realize the importance of cleanliness and segregation of waste.

Local government (Urban Village) need to find new land and build TPS with permanent buildings to accommodate the waste generation in each RT (neighborhood unit) location. Because the temporary disposal sites were deemed unsuitable, a lot http://ojs.unud.ac.id/index.php/eot of trash was scattered and gave off an unpleasant smell. There needs to be a plan to move (relocate) the temporary garbage dump to a TPS location with a permanent building. Treatment and volume of waste must be carefully calculated so that the existing infrastructure and facilities can function optimally

\section{ACKNOWLEDGEMENT}

The author would like to thank RISTEK-BRIN (Ministry of Research and Technology / National Research and Innovation Agency) of the Republic of Indonesia who has given assistance in the form of finance and providing research funding. The author also thanked Bogor School of Tourist (STP Bogor) who giving the opportunity to the author as a lecturer to do Field Research at the Cimande Tourist Village.

\section{REFERENCES}

Evered, R., \& Selman, J. (1989). Coaching Sales Performance: A Case Study. Organizational Dynamic, XVII(2), 16-32.

Grant, A. (2003). The Impact of Life Coaching on Goal Attainment, Metacognition and Mental Health. Social Behavior and Personality, 31(3), 253-264. 
Hadi Atmoko, P. T. (2014, November). Strategi Pengembangan Potensi Desa Wisata Brajan Kabupaten Sleman. Jurnal Meda Wisata, XII(2), 146-154.

Heriyantara, A., Kasmita, \& Waryono. (2015). Pengelolaan Sapta Pesona di Objek Wisata Pantai Padang. ejournal Universitas Negeri Padang.

Hermawan, H. (2016, September). Dampak Pengembangan Desa Wisata Nglanggeran Terhadap Ekonomi Masyarakat Lokal. Jurnal Pariwisata, III(2), 105-117.

Ives, Y. (2008, August). What is 'Coaching' An Exploration of Conflicting Paradigms. International Journal of Evidence Based Coaching and Mentoring, VI(2), 100.

Khalik, Wahyu. 2014. Kajian Kenyaman dan Keamanan Wisatawan di Kawasan Pariwisata Kuta Lombok. JUMPA. I (1). 23-42

Kodoatie, R. J. (2005). Manajemen dan Rekayasa Infrastruktur. Yogyakarta: Pustaka Pelajar.

Masjhoer, J. M. (2017, Mei 2). Kajian Pengelolaan Sampah di Kawasan Wisata Pantai Parangtritis Kabupaten Bantul. Jurnal Kepariwisataan, XI(2), 41-58.

Musa, F. M. (2014). Penerapan Sapta Pesona Pada Desa Wisata Torosiaje Dalam Menunjang Kepariwisataan Di Kabupaten Pohuwato. eprints Universitas Negeri Gorontalo.

Parsloe, E., \& Wray, M. (2000). Coaching and Mentoring. Kogan Page.
Prabowo, M. S. (2015). Evaluasi Penerapan Program Sapta Pesona Untuk Meningkatkan Kepuasan Wisatawan Di Wisata Alam Pangjugjugan Kabupaten Sumedang :. Repository Universitas Pendidikan Indonesia.

Roger, C. (1959). A theory of therapy, personality and interpersonal relationship, in Kochm, SW. (ED). Pschology: A study of Science, 184256.

Siahaan, J. (2016). Prediksi Kondisi Sampah Di Tempat Pengelolaan Sampah Terpadu (TPST) Siosar dan Solusi Pemecahan Masalahnya Dalam Upaya Meretensi Gas Rumah Kaca. Sumatera Utara: Universitas Sumatera Utara.

Stober, D., Wildflower, \& Drake. (2006). Evidence-Based Practice: A Potential Approach for Effective Coaching. International Journalof EvidenceBased Coaching, 4(1).

Sugiarto, P., Hendratono, T., \& Djoko, S. (2015). Metodologi Penelitian Hospitality \& Pariwisata. Tangerang: Matana Publishing.

Sugiyono, P. D. (2016). Metode Penelitian Manajemen (Pendekatan Kuantitatif, Kualitatif, Kombinasi (Mixed Methods), Penelitian Tindakan (Action Research, dan Penelitian Evaluasi). Bandung: Alfabeta Cv.

Taufiq, M. F. (2018, May). Manajemen Pengelolaan Sampah Berkelanjutan Melalui Inovasi "Ecobrick" Oleh Pemerintah Kota Yogyakarta. ResearchGate.

Whitmore, J. (2003). In N. B. Publishing, Coaching for Performance. London. 